\title{
Relation between Age of Onset of Obesity and Size and Number of Adipose Cells
}

\author{
C. G. D. BROOK, JUNE K. LLOYD, O. H. WOLF
}

British Medical fournal, 1972, 2, 25-27

\section{Summary}

The size and number of adipose cells in obese children and adults were compared with control data. An increase in adipose cell size was found in all the obese subjects. The total number of adipose cells was increased in those children who had become obese already by the age of 1 year and in those adults who dated their obesity to childhood.

\section{Introduction}

Studies in adults have shown that the increase in adipose tissue which occurs in obesity may be due to enlargement of existing fat cells, or to increase in the total number of fat cells, or to a combination of both processes (Bjorntorp and Sjöström, 1971). Hirsch and Knittle (1970) showed that in obese adults who have an increased number of adipose cells the obesity is likely to have dated from childhood.

Overfeeding of rats in the first three weeks of life, before weaning, has been shown to have lasting consequences both on body weight (Widdowson and McCance, 1960) and on the cellularity of adipose tissue (Knittle and Hirsch, 1968). Thus animals which had excessive food intake in the early weeks of life tend to remain heavier and to have more adipose cells than litter mates who received less food at a similar period. In babies excessive weight gain during the first six months of life is associated with an increased incidence of obesity in later childhood (Asher, 1966; Eid, 1970).

Department of Child Health, Institute of Child Health, London WCIN 1EH

C. G. D. BROOK, M.D., M.R.C.P., Lecturer

JUNE K. LLOYD, M.D., F.R.C.P., Reade

O. H. WOLFF, M.D., F.R.C.P., Professor
The present paper relates differences in adipose cell size and number to the age of onset of obesity in both children and adults.

\section{Patients}

Fifty-four obese children and 25 obese adults were studied; details are shown in Tables I and II. The weight of all the obese children exceeded that expected for their height by at least $20 \%$, and their triceps and subscapular skinfold thicknesses were over the 90th percentile (Tanner and Whitehouse, 1962). In adults excess weight for height was not used as a criterion of obesity in view of the wide limits of "normality" resulting from differences in body shape; in these patients skinfold thickness was used as the sole criterion; and all patients had triceps and subscapular skinfold thicknesses above the 95th percentile (15 mm for men and $25 \mathrm{~mm}$ for women). None of the patients was suffering from any defined endocrine disorder.

The age of onset of obesity in the children was determined from the history obtained from the parents and from objective weight records obtained from infant welfare clinics and hospital notes. A weight at 1 year of age which was above the 97th percentile on standard charts (Tanner et al., 1966), together with evidence that percentile lines had been crossed during the first year of life, was taken as evidence of excessive weight gain during this period. Such data were available for 43 of the 54 children. In the remaining 11 a single observation of a weight over the 97th percentile at 1 year of age, supplemented by photographic evidence of obesity, was accepted as an indication of excessive weight gain in the first year of life.

The age of onset of obesity in the adult patients was ascertained by history alone, as it proved impossible to obtain objective records. These data are obviously less reliable than those obtained for the children and do not provide evidence regarding the presence or absence of obesity in the first year of life.

TABLE I-Degree of Obesity and Adipose Cell Size in Children

\begin{tabular}{|c|c|c|c|c|c|c|c|c|}
\hline & & \multirow{2}{*}{$\begin{array}{l}\text { No. of } \\
\text { Subjects }\end{array}$} & \multicolumn{2}{|c|}{ Sex } & \multirow{2}{*}{ Age Range (Years) } & \multirow{2}{*}{$\begin{array}{c}\text { \% Overweight } \\
\text { (Mean and Range) }\end{array}$} & \multirow{2}{*}{$\begin{array}{l}\text { B. Body Weight as Fat } \\
\text { (Mean } \pm \text { I S.D.) }\end{array}$} & \multirow{2}{*}{$\begin{array}{c}\text { Adipose Cell Size ( } \mu \mathrm{g} \\
\text { Lipid/Cell) } \\
\text { (Mean } \pm 1 \text { S.D.) }\end{array}$} \\
\hline & & & M. & F. & & & & \\
\hline All obese children ... & . & 54 & 18 & 36 & $0.8-16.6$ & \multirow{4}{*}{$\begin{array}{c}53 \cdot 0 \\
(20 \cdot 0-141 \cdot 0) \\
52 \cdot 3 \\
(25 \cdot 5-100 \cdot 0) \\
52 \cdot 7 \\
(20 \cdot 0-141 \cdot 0) \\
=\end{array}$} & $37 \cdot 5 \pm 4 \cdot 6$ & $0.70 \pm 0.19$ \\
\hline Early onset (group E) & $\cdots$ & 29 & 11 & 18 & $0.8-14 \cdot 8$ & & $38 \cdot 2 \pm 5 \cdot 0$ & $0.64 \pm 0.18$ \\
\hline Late onset (group L) & . & 25 & 7 & 18 & $3.4-16.6$ & & $36 \cdot 7 \pm 4 \cdot 0$ & $0.77 \pm 0.17$ \\
\hline Control children & .. & 64 & 46 & 18 & $0.3-17 \cdot 7$ & & $17 \cdot 5 \pm 6.8$ & $0.30 \pm 0.14$ \\
\hline
\end{tabular}

Cells of obese children contained more lipid than controls $(P<0.001)$.

Cells of group $E$ children contained less lipid than those of group $\mathrm{L}(\dot{P}<0.01)$

There was no difference in the degree of fatness between children of groups $E$ and $L$.

TABLE II-Degree of Obesity and Adipose Cell Size in Adults

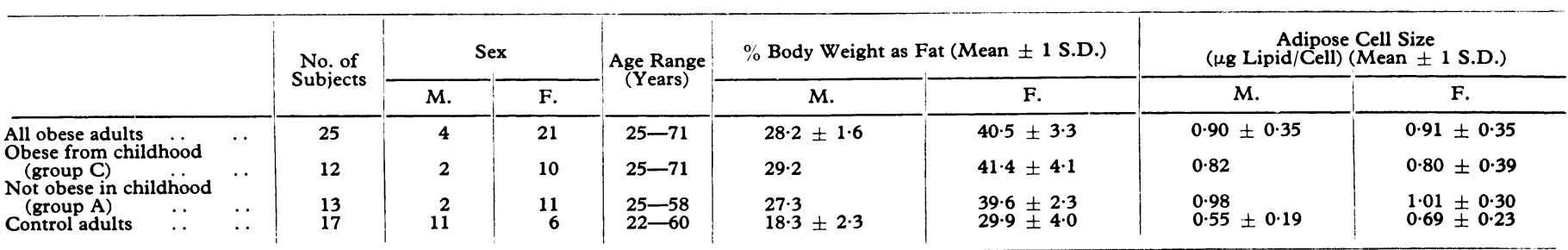


Control data were obtained from 64 children and 17 adults undergoing elective surgery who were otherwise healthy and were not obese, using the criterion of skinfold thickness.

\section{Methods}

All subjects were weighed to the nearest $0.1 \mathrm{~kg}$ in underclothes on beam scales, and their height was measured with a stadiometer. Skinfold thicknesses were measured on the left side at four sites (biceps, triceps, subscapular, and suprailiac), a Harpenden skinfold caliper being used in the standard manner (Edwards et al., 1955). Total body fat was calculated from the skinfold measurements; the regression equations of Durnin and Rahaman (1967) were used for children over 12 years and for adults and the regression equations of Brook (1971a) for children under 12 years.

A sample of adipose tissue (about $20 \mathrm{mg}$ ) was obtained from the obese subjects by aspiration from subcutaneous tissue (usually buttock or arm) and from the controls from subcutaneous tissue at the operation site at elective surgery. Adipose cell lipid content (a measure of adipose cell size) was estimated by a minor modification (Brook 1971b) of the method of Hirsch and Gallian (1968). The total number of adipose cells in the body was calculated from the mean weight of lipid per cell and the total body fat. Because cells from deep sites are smaller than those from superficial sites (Brook, 1971b), the total number of adipose cells was probably slightly underestimated.

\section{Results}

These are summarized in the Tables and Figures. Of the 54 obese children 29 were already obese by the age of 1 year (early onset, group E). In 25 the onset of obesity was later (late onset, group L). Of the 25 obese adults 12 dated their obesity to childhood (group C) and 13 stated that they had become obese only in adult life (group A). In the children the degree of fatness did not differ between groups $\mathrm{E}$ and $\mathrm{L}$; and in the adults there was no difference between groups $\mathrm{C}$ and $\mathrm{A}$.

Adipose Cell Size.-The cells of group E children were significantly smaller than those of group L, but in both groups the cells were significantly larger than those of controls; there were no sex differences. The cells of obese men and women were larger than those of controls; although the cells of group C adults, both men and women, tended to be smaller than those of group A, this difference was not statistically significant. The data for the adults are presented for the sexes separately because women have more body fat than men, and because in the control groups the mean cell size of the women was greater than that of the men, although this difference did not reach statistical significance.

Adipose Cell Number.-The total number of cells in children has to be considered in relation to age, the number increasing until puberty, when adult values are reached (Brook, 1971c). No sex differences have been detected in either children or adults. Fig. 1 shows the curves for mean values and standard deviations according to age obtained from the observations on 64 nonobese children and 17 non-obese adults. For construction of these curves the data have been split into two-year age groups and means and standard deviations for each group calculated, after confirming on probability paper that the distributions were not obviously different from Gaussian. The curves have been fitted by eye. The values of fat cell number for individual obese children are also shown in Fig. 1. The number of cells in children in group $\mathrm{E}$ was significantly increased, but the number in group $L$ fell within the normal range. The number of adipose cells in individual obese adults is shown in Fig. 2. The mean number of cells in group $\mathrm{C}$ was significantly greater than that in group $A(P<0.01)$, but the number in group $A$ did not differ significantly from that in the controls.

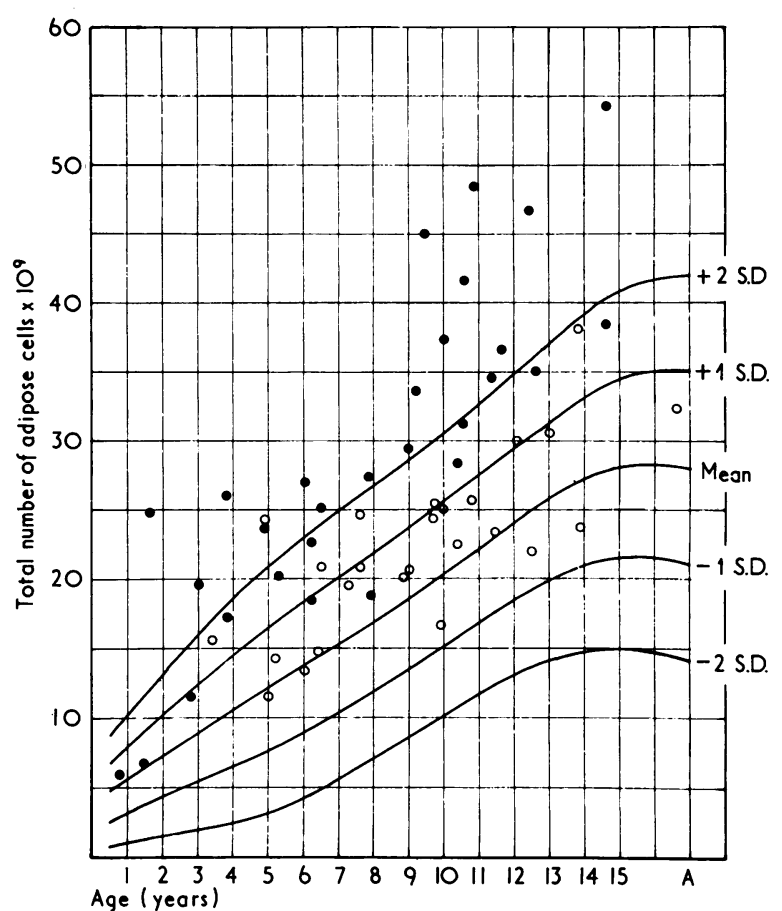

FIG. 1-Total number of adipose cells in obese children. Children already obese by age of 1 year. $O=$ Children with onset of obesity in later childhood.

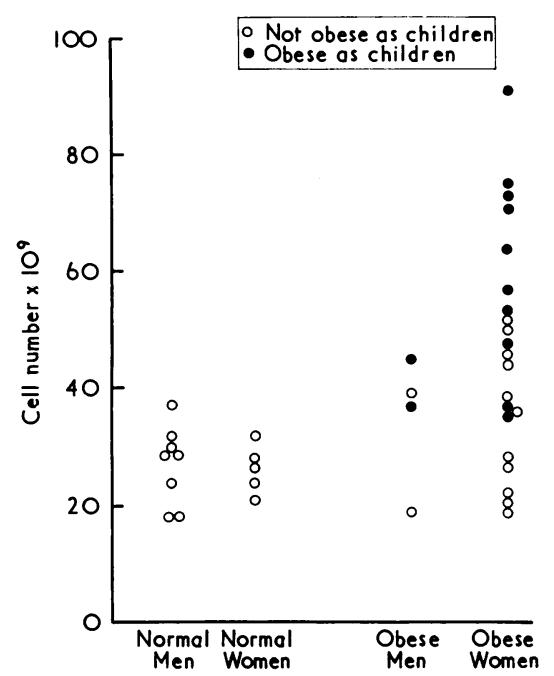

FIG. 2-Total number of adipose cells in adults.

\section{Discussion}

The present study shows that whereas all the obese individuals had an increase in the size of fat cells, in only a proportion was the total number of cells also increased, and an increased number of cells was associated with the age of onset of obesity; thus in the children increased cellularity was found in those who had gained weight excessively during the first year of life, and in the adults an increased number of cells occurred in those who had a history of obesity dating from childhood. Although the age of onset of obesity in the adult patients has not been securely established, it seems probable that those who admitted to being overweight as children were obese, even if the exact time of onset during the childhood years cannot be ascertained.

Early growth of the adipose organ in rats has been shown to be accompanied by increase in both the number and size of adipose cells (Hirsch and Han, 1969). After the 15th week of extrauterine life, however, no further increase in the number of adipose cells occurs and further growth can take place only by cell enlargement; at this age the skeletal maturation of a rat is 
99\% complete (Hughes and Tanner, 1970) and the equivalent age in human terms (based on bone age) would be about 16 years. In adult life changes in weight in rats (Hollenberg and Vost, 1968) and in humans (Hirsch et al., 1966; Sims et al., 1968) have been found to correlate well with changes in adipose cell size, but total cell numbers are not affected.

It therefore seems that the total number of adipose cells becomes fixed towards the end of childhood, and the results of our investigations in obese children suggest that the period during which the rate of fat cell multiplication is most affected by overnutrition extends to about the age of 1 year. It may be relevant that also at about this age the skinfold thicknesses in normal infants stop increasing (Tanner and Whitehouse, 1962). It seems likely that during this sensitive period the basic complement of fat cells for an individual is established and that thereafter cell multiplication proceeds at a normal rate, regardless of nutritional circumstances, changes in which are reflected by changes in adipose cell size.

It has been shown that the total number of adipose cells cannot be reduced by dieting, either in obese adults (Salans et al., 1968) or in children (Brook, 1971c). It is not yet known, however, whether the rate of multiplication of adipose cells during later childhood can be arrested by relative undernutrition, nor whether infants who have laid down an increased number of cells during the first year of life may be expected to maintain this increase even if dietary intake is subsequently curtailed. Studies of the natural history of childhood obesity (Lloyd et al., 1961) show that obesity persists into adult life in about $80^{\circ}{ }_{0}$ of children, but no investigation has been made relating the age of onset of the obesity to the outcome in individual children. Prospective studies are required to determine whether children whose obesity started in the first year of life and who have an increased number of adipose cells have a different prognosis from those whose obesity started later and whose adipose cell number is normal.

We would like to thank Dr. I. McLean Baird for his help in studying obese adult patients and the surgical staff of the Hospital for Sick Children, Great Ormond Street, the Royal National Orthopaedic Hospital, Stanmore, and St. Thomas's Hospital for obtaining samples of adipose tissue in the control patients. C.G.D.B. gratefully acknowledges the receipt of a Wellcome Research Fellowship.

\section{References}

Asher, P. (1966). Archives of Disease in Childhood, 41, 672

Bjorntorp, P., and Sjöström, L. (1971). Metabolism, 20, 703.

Brook, C. G.'D. (1971a). Archives of Disease in Childhood, 46, 182.

Brook, C. G. D. (1971b). British fournal of Nutrition, 25, 377

Brook, C. G. D. (1971c). Obesity in Childhood. MD Thesis, University of Cambridge.

Durnin, J. V. G. A., and Rahaman, M. M. (1967). British fournal of Nutrition, 21, 681 .

Edwards, D. A. W., Hammond, W. H., Healey, M. J. R., Tanner, J. M., and Whitehouse, R. H. (1955). British fournal of Nutrition, 9, 133.

Eid, E. E. (1970). British Medical fournal, 2, 74

Eid, E. E. (1970). British Medical fournal, 2, 74.

Hirsch, J., and Gallian, E. (1968). Fournal of Lipid Research, 9, 110

Hirsch, J., and Han, P. W. (1969). Fournal of Lipid Research, 10, 77.

Hirsch, J., and Knittle, J. L. (1970). Federation Proceedings, 29, 1516. Hirsch, J., Knittle, J. L.,

Hollenberg, C. H., and Vost, A. (1968). Journal of Clinical Investigation, 47,2485

Hughes, P. C. R., and Tanner, J. M. (1970). Fournal of Anatomy, 106, 371.

Knittle, J. L., and Hirsch, J. (1968). Fournal of Clinical Investigation, 47, 2091

Lloyd, J. K., Wolff, O. H., and Whelen, W. S. (1961). British Medical

Fournal, 2, 145 .
Salans, L. B., Knittle, J. L., and Hirsch, J. (1968). Fournal of Clinical Investigation, 47, 153

Sims, E. A. H., et al. (1968). Transactions of the Association of American Physicians, 81, 153.

Tanner, J. M., and Whitehouse, R. H. (1962). British Medical fournal, 1, 446 Tanner, J. M., and Whitehouse, R. H. (1962). British Medical fournal, 1, 446. Disease in Childhood, 41, 454, 613 .

Widdowson, E. M., and McCance, R. A. (1960). Proceedings of the Royal Society. Series $B, 152,188$.

MEDICAL MEMORANDA

\section{Reversible Renal Failure with Renal Artery Occlusion}

\section{O. P. QUANTOCK, G. N. THATCHER}

\section{British Medical fournal, 1972, 2, 27-28}

Acute occlusion of the main renal artery whether by trauma, embolism, or thrombosis produces acute failure of function of that kidney. Return of renal function can be expected if the obstruction is removed within a few hours. There are reports of return of renal function after delayed surgical revascularization, however, even when this is delayed up to 39 days (Perkins et al., 1967). Viability but not function is presumably maintained by collateral renal vessels (Love and Bush, 1968). Spontaneous recovery of function after unilateral renal artery occlusion has been described (Bellman and Odén, 1960; Heitzman and Perchik, 1961; Fergus et al., 1969). We report a case of acute renal failure in a patient with only one kidney in whom occlusion of the renal artery occurred and in whom life-sustaining renal function returned spontaneously after prolonged dialysis.
A 48-year-old man was investigated for accelerated hypertension in March 1966. His blood pressure was $240 / 170 \mathrm{~mm} \mathrm{Hg}$, blood urea $66 \mathrm{mg} / 100 \mathrm{ml}$, and creatinine clearance $47.5 \mathrm{ml} / \mathrm{min}$. I.V.P. showed a non-functioning right kidney. An aortogram showed gross stenosis at the origin of the right renal artery. There was stenosis at the origin of the left renal artery and poststenotic dilatation. A right nephrectomy was performed and a Teflon graft placed between the left common iliac artery and the poststenotic portion of the left renal ortery (Fig. 1). Biopsy of the left kidney showed features of gross ischaemia. Postoperatively his blood

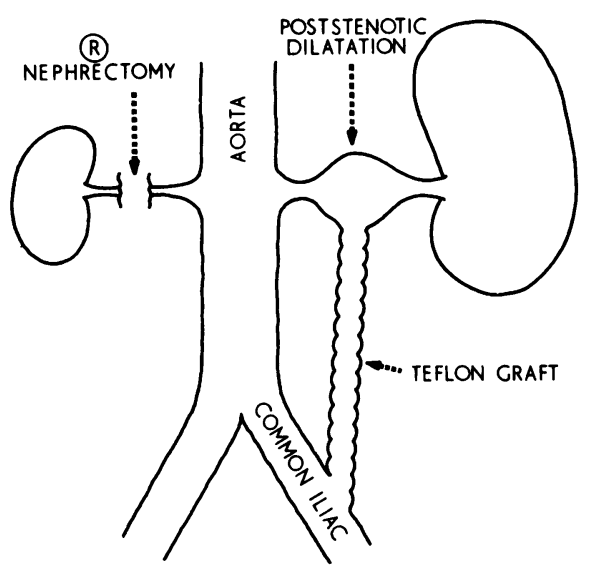

FIG. 1-Diagram of postoperative renovascular status (1966). 